\title{
Piotr Garczewski*
}

Uniwersytet Gdański

\section{FENOMENOLOGICZNA JEDNOŚĆ DOŚWIADCZENIA PSYCHODELICZNEGO - ANALIZA TREŚCI TRIP RAPORTÓW}

\begin{abstract}
W prezentowanym tekście autor podejmuje próbę zmierzenia się ze skrajnie subiektywnymi i na pozór nieprzystającymi do siebie jednostkowymi doświadczeniami z zakresu odmiennych stanów świadomości. Jego celem jest ukazanie fenomenu doświadczenia psychodelicznego jako poddającego się obiektywizacji i tym samym spójnego przeżycia, w wyniku analizy opowieści osób, które w sposób bezpośredni go doświadczyły na drodze zażywania określonych środków psychoaktywnych. Czerpiąc inspiracje od grupy zaangażowanych w amerykańską kontrkulturę lat 60' harvardczyków, którzy przy próbach opisania fenomenu tego zjawiska odwoływali się do filozofii i religii Wschodu, autor proponuje język opisu i narzędzia analityczne bazujące na filozofii i naukach społecznych gruntu europejskiego.
\end{abstract}

Słowa kluczowe: odmienne stany świadomości, doświadczenie psychodeliczne, socjologia fenomenologiczna, Alfred Schütz

\section{ŹRÓDŁO INSPIRACJI}

W latach 60’ grupa harvardzkich psychologów, którą tworzyli Timothy Leary, Ralph Metzner oraz Richard Alpert, postawiła sobie za cel nadanie fenomenowi doświadczenia psychodelicznego dyskursywnego charakteru, dzięki skojarzeniu go z filozofią Wschodu. Dzięki temu napisany został podręcznik ${ }^{1}$ inspirowany Tybetańska Księga Umarlych (Bar-do thos-grol), w którym to harvardczycy instruowali krok po kroku, jak przygotować się do psychodelicznego doświadczenia i bezpiecznie przez nie przejść, tworząc jego swoistą mapę dzięki zestawieniu jego kolejnych etapów ze stanami bardo. Był to pomysł nowatorski i wpisujący się doskonale w charakter Ery Wodnika. Jego cel nie był jednak, jak mogłaby sugerować profesja autorów, naukowy, a przynajmniej nie wskazuje na to jego realizacja. Doświadczenie psychodeliczne miało nade wszystko wartość edukacyjną dla zagubionych i nieumiejących poradzić sobie z nową ambrozją młodych hipisów i kontestatorów. Połączenie myśli i filozofii

* Adres do korespondencji: Piotr Garczewski, Instytut Pedagogiki, Wydział Nauk Społecznych Uniwersytetu Gdańskiego; e-mail: piotr.garczewski@gmail.com.

1 Wydanie polskie: Timothy Leary, Ralph Metzner, Richard Alpert. 2011. Doświadczenie psychodeliczne. Podręcznik inspirowany Tybetańska Księga Umarlych, Warszawa: Okultura. 
Wschodu z zachodnią rewolucją psychodeliczną dzięki kulturowemu transferowi wiedzy przyniosło efekt w postaci transkulturowej hybrydy, która nie przetrwała jednak próby czasu i nie przyjęła się na stałe w środowisku współczesnych amatorów psychodelicznych podróży. Liczba tych amatorów jednak, jak pokazują obserwacje choćby nocnego życia klubowego, festiwali muzycznych czy pewnych obszarów internetowej sieci, jest dziś całkiem pokaźna także w Polsce ${ }^{2}$. Skoro korzystanie z potencjału środków psychodelicznych jest w pewnych kręgach wciąż popularne, to z pewnością warto spróbować zrozumieć i przybliżyć ich fenomen, korzystając z wiedzy i narzędzi pochodzących z naszego gruntu kulturowego.

\section{OBSZAR PROWADZONYCH BADAŃ I ICH PRZEDMIOT}

Na potrzeby prowadzonych badań autor analizował treści zamieszczane na dwóch spokrewnionych ze sobą forach internetowych: talk.hyperreal.info ${ }^{3}$ i neurogroove.info, powstałych w ramach serwisu Hyperreal.info, poświęconego tematyce środków psychoaktywnych. Serwis ten istnieje od 1996 r. i gromadzi informacje w postaci artykułów naukowych, pseudonaukowych, wywiadów, recenzji, na temat środków psychoaktywnych oraz polityki narkotykowej zarówno w Polsce, jak i na świecie. Domena talk.hyperreal.info, przynależąca do platformy Hyperreal.info, spełnia funkcję forum dyskusyjnego podzielonego na następujące działy tematyczne: substancje psychoaktywne na co dzień; konopie; magiczny ogród; (al)chemia umysłu; chemia substancji psychoaktywnych; hyperreal. Liczba zarejestrowanych użytkowników w okresie prowadzenia badań na dzień 12.11.2012 r. sięgała blisko 93 tysięcy osób i była to wartość, która w ciagu roku od listopada $2011 \mathrm{r}$. wzrosła o ponad 15 tysięcy ${ }^{4}$. Liczba internautów mających konta na forum hyperreal.info/talk na dzień 14.02.2014 r. wynosiła dokładnie 109424 użytkowników. Ogólna liczba wszystkich wątków zamieszczonych na forum talk.hyperreal.info na ten sam dzień wynosiła 23755 , przy 1325351 postach $^{5}$.

Od 2002 roku domena hyperreal.info udostępniała także dział Neuro Groove, który od roku 2009 wyodrębnił się jako samodzielny serwis pod adresem neurogroove.info. Platforma ta wykorzystywana jest do publikowania opisów przeżyć internautów, doznawanych dzięki testowaniu na sobie różnego rodzaju substancji, roślin bądź grzybów o właściwościach psychodelicznych. Twórcy serwisu wskazują, iż jego celem jest przede wszystkim

[...] zapewnienie wymiany informacji pomiędzy osobami zainteresowanymi własnymi przeżyciami wywołanymi substancjami psychoaktywnymi. [...] Zdaniem twórców NG, jeśli ktoś decyduje się

2 Nie bez kozery choćby Encyklopedia psychodeliczna K. Sipowicza została wydana właśnie teraz, i choć jest to tylko autorska refleksja, wydaje się, że mamy dziś do czynienia ze swoistym psychodelicznym renesansem, który możliwy jest choćby dzięki popularyzacji i ułatwionemu dostępowi do tzw. designer drugs, które bez większego problemu można nabyć za pośrednictwem internetu.

3 Od czasu zakończenia badań strona zmieniła adres na: hyperreal.info/talk.

4 Dane pochodzą z obserwacji własnych i notatek na temat funkcjonowania serwisu sporządzonych jeszcze w 2011 roku pokazują, że od listopada 2011 r. do lutego 2014 r. liczba zarejestrowanych użytkowników wzrosła o blisko 31,5 tysiąca. Według informacji zamieszczonej na stronie (http://neurogroove.info/o-co-tu-chodzi), jeszcze w kwietniu 2011 r. liczba zarejestrowanych użytkowników wynosiła około 50 tysięcy.

5 Hyperreal.info/talk [14.02.2014]. 
Fenomenologiczna jedność doświadczenia psychodelicznego - analiza treści trip raportów

na przyjęcie narkotyku (rośliny, leku, używki) - powinien móc przygotować się do tego możliwie najbezpieczniej, hołdując mottu ,know your body, know your mind, know your substance, know your source”, co w wolnym thumaczeniu brzmi: „znaj umiar, zachowaj przytomność, odrób lekcje, kupuj najczyściej lub wcale”. Trip raporty nadsyłane przez użytkowników stanowią źródło informacji o efektach działania konkretnych substancji i są dopełnieniem innych informacji na ich temat ${ }^{6}$. [...] Serwis neurogroove.info jest odpowiednikiem działu tematycznego powstałego w ramach zagranicznej platformy Erowid.org, która podobnie jak Hyperreal.info, gromadzi dane dotyczące substancji psychoaktywnych? .

Podstawą wyróżnienia Neuro Groove jako samodzielnego serwisu są publikowane w jego ramach treści, czyli trip raporty. Stanowią one opis przeżyć, wywołanych na skutek zażycia określonych substancji psychoaktywnych. Jest to zwrot, który funkcjonuje w powszechnym użyciu co najmniej od lat 50-60. ubiegłego wieku, gdyż przeżycia psychodeliczne określał mianem tripów wspomniany Timothy Leary, jeden z ojców amerykańskiej kontestacji lat 60. (Leary 1998: 2-3). Słowo „raport” odsyła do formy opisu, która powinna mieć charakter retrospektywnej, bądź zdawanej jeszcze w trakcie doświadczenia, maksymalnie dokładnej relacji, sprawozdania z jego przebiegu. Twórcy serwisu, wzorując się na raportach publikowanych w ramach serwisu Erowid.org, wskazują na to, że poprawny opis doświadczenia, poza pewnymi kwestiami co do stylistyki, języka i formatowania tekstu, powinien odnotowywać następujące kwestie: Set\&Setting (nastawienie mentalne osoby zażywającej i okoliczności zażycia); możliwie precyzyjne dawkowanie substancji; wiek użytkownika oraz doświadczenie w dotychczasowym kontakcie z substancjami psychoaktywnymi; czas trwania przeżycia i wyszczególnione jego najważniejsze momenty (choćby peak, czyli szczyt doświadczenia); rodzaj przeżycia (czy było to przeżycie pozytywne, negatywne, czyli tak zwany bad trip, czy na przykład przeżycie mistyczne) $)^{8}$. Słowo trip nawiązuje do specyfiki doświadczenia, które zwłaszcza w przypadku zażywania psychodelików (czyli jednej z podgrup w ramach szerszego zbioru substancji psychoaktywnych ${ }^{9}$ ) w subiektywnej ocenie osób zażywających, odczuwane i tłumaczone jest jako ,podróż”, którą należy rozumieć w sensie zarówno dosłownym, jak i metaforycznym. Dosłowność wyraża się tutaj w popularności i skłonności do organizowania wędrówek pod wpływem określonych substancji, roślin bądź grzybów, które stymulują użytkowników do tego typu aktywności. W sensie metaforycznym trip rozumiany też musi być jako symboliczna podróż poza obszary własnego ja, poza umysł czy też świadomość, o których doświadczaniu raportują tripujące osoby.

Trip raporty, skatalogowane są zgodnie z kryterium specyfiku, który był bezpośrednią inspiracją do napisania danego tekstu. Serwis daje użytkownikom możliwości porządkowania ich doświadczeń w ramach trzech głównych kategorii: „Natura”, „Chemia” i „Apteka”, które odsyłają do konkretnych roślin, grzybów bądź substancji chemicznych. Biorąc pod

\footnotetext{
Neurogroove.info/o-co-tu-chodzi [14.02.2014].

Neurogroove.info/o-co-tu-chodzi [14.02.2014].

Neurogroove.info/jak-napisac-poprawny-raport [30.04.2013].

Dobrze obrazuje to diagram Venna zamieszczony na portalu Wikipedia, który zawiera zestawienie najpopularniejszych substancji psychoaktywnych w podziale na grupy i podgrupy. Zob.: https://pl.wikipedia. org/wiki/Substancja_psychoaktywna.
} 
uwagę 10 najpopularniejszych substancji, roślin bądź grzybów odpowiadających konkretnej z kategorii, czyli w ramach w sumie 30 podkategorii, w trakcie badań na Neuro Groove zamieszczonych było dokładnie 2145 trip raportów, do których należy doliczyć kilkadziesiąt pojedynczych raportów dotyczących mało popularnych specyfików oraz ponad 190 raportów odrzuconych ze względu na naruszanie regulaminu ${ }^{10}$. Na początku 2014 r. serwis gromadził zatem blisko 2,5 tysiąca opisów odmiennych stanów świadomości, wywołanych na skutek stosowania ponad 100 różnych substancji psychoaktywnych.

W przeprowadzonym badaniu przeanalizowano 100 trip raportów opisujących doznania po zastosowaniu wyłącznie substancji psychodelicznych: LSD, różnych odmian grzybów psylocybinowych oraz związku o nazwie 4 HO-MET. Wybór trip raportów odwołujących się akurat do tych konkretnych środków, wynikał z kilku przesłanek. Po pierwsze uwzględnić chciano doświadczenia przeżywane zarówno pod wpływem sztucznych substancji chemicznych jak i enteogenów, czyli psychodelików naturalnych. Po drugie brana pod uwagę była kategoria popularności danej substancji czy związku. Grzyby halucynogenne zajmują drugie, po marihuanie, miejsce pod względem ilości raportów w kategorii natura (161 raportów). LSD jest najczęściej opisywanym związkiem chemicznym (158 raportów). 4 HO-MET jest natomiast chemiczną substancją wynalezioną przez farmakologa Alexandra Shulgina, strukturalnie analogiczną do psylocyny. Zajmowała ona trzecie miejsce, jeżeli chodzi o popularność w kategorii chemia (95 raportów). Jej uwzględnienie spowodowane jest swoistą modą na stosowanie research chemicals, czyli substancji oznaczanych jako odczynniki chemiczne, materiały kolekcjonerskie, „narkotyki projektowane”, które można legalnie zakupić za pośrednictwem internetu. Po trzecie natomiast, biorąc także pod uwagę popularność, w porównaniu z pozostałymi substancjami i roślinami, wybrane do badania psychodeliki mają stosunkowo największy potencjał wprowadzania w odmienne stany świadomości, za co są powszechnie cenione zarówno wśród użytkowników forum, jak i w środowisku badawczym ${ }^{11}$.

\section{TRIP RAPORT JAKO NARRACJA BIOGRAFICZNA}

Mając do czynienia z danymi zastanymi w postaci tekstu, zawieszonego w przestrzeni internetowego forum, o których po wstępnej analizie wiedziano, że przesycone są one silnym wartościowaniem i emocjami, konieczne było odwołanie się do takiej metody, która pozwoliłaby na zaadaptowanie ich na potrzeby socjologicznej analizy. W tym przypadku wartościowe okazało się nawiązanie do bogatej tradycji stosowania metody biograficznej w socjologii polskiej, rozwijanej przez F. Znanieckiego, J. Chałasińskiego oraz J. Szczepańskiego, którzy zasłynęli z analiz pamiętnikarskich (Włodarek i Ziółkowski 1990: 3-4). Metoda biograficzna w ich przypadku sprawdzała się przy prowadzenia pogłębionych refleksji

10 Neurogroove.info [26.02.2014].

11 Meskalina czy DMT (dimetylotryptamina) są co prawda również bardzo silnymi psychodelikami, jednak popularność ich stosowania w Polsce jest niewielka. Grzyby z gatunków grzybów psylocybinowych mają natomiast silniejsze działanie psychodeliczne niż marihuana. 
na temat indywidualnego podmiotu i doświadczanej przez niego w sposób subiektywny rzeczywistości społecznej, dzięki zwróceniu uwagi na fakt, że przez opowiadanie historii i narrację ludzie dążą do uporządkowania swojego rozumienia świata. Socjologowie analizujący biografie dostrzegli w nich potencjał odkrywania trudno dostępnego świata doświadczeń subiektywnych, zwracając uwagę, że tego typu opowieści przesycone są sensami, jakie swoim doświadczeniom nadają jednostki (Gibbs 2011: 108). Na potrzeby prowadzonego badania każdy trip raport potraktowano jako osobiste świadectwo i retrospektywny opis zdarzeń i doświadczeń dotyczących danej jednostki bądź grupy osób (w przypadku tripów zbiorowych), tutaj forumowiczów, internautów.

Trip raporty skatalogowano zgodnie z nickiem użytkownika i załadowano do bazy programu do jakościowej analizy danych NVIVO 10, gdzie jako dane biograficzne podlegały procedurze kodowania, bez narzucanych wcześniej kategorii kodowych (w ten sposób realizowana była przesłanka płynąca z tradycji badań biograficznych, aby subiektywna perspektywa osoby badanej była punktem wyjścia uogólnień teoretycznych). Analogicznie do powyższego, niezbędne było także obudowanie analizy taką warstwą filozoficzno-teoretyczną, która byłaby nie tylko spójna z zaproponowaną metodologią, ale także pasowała do specyfiki materiału, poddanego uwadze badawczej. W parze z metodą biograficzną zestawiono ufundowaną na myśleniu w duchu Verstehen socjologię fenomenologiczną w wydaniu Alfreda Schütza, która dostarczyła teoretycznej ramy dla celów postępowania analityczno-interpretatywnego. $\mathrm{Na}$ bazie ugruntowanego podejścia do analizy zostało w konsekwencji wyłonionych ponad 20 kategorii kodowych, które pozwoliły na podjęcie próby teoretycznego zrekonstruowania fenomenu doświadczenia psychodelicznego.

\section{RAMA ANALITYCZNO-TEORETYCZNA}

Doświadczenie psychodeliczne jest jakościowo unikalnym i trudnym do uchwycenia, ze względu na swój silnie subiektywistyczny charakter, zjawiskiem, które należy uznać jednocześnie za odmienny od codziennego stan bycia. Odznacza się ono, podobnie jak i inne doświadczenia, takie jak sen, fantazja, oświecenie czy refleksja naukowa, tym, że wyciaga nas niejako $\mathrm{z}$ naturalnego dla nas stanu bycia w ramach świata życia codziennego, jak nazywał go Schütz (Lejzerowicz-Zajączkowska 2003: 126). W ramach ogólnego świata życia - Lebenswelt, funkcjonujemy zatem nie tylko w świecie życia codziennego, ale także w innych mikroświatach czy dziedzinach znaczenia, które wyróżniają się odmiennymi stylami poznawczymi. Każde z tych mikroświatów odróżnialne są wyraźnie nie tylko od świata życia codziennego, ale także od siebie nawzajem. Oznacza to, że swoiste cechy posiada jako odrębne doświadczenie zarówno sen, przeżycie religijne, fantazja, refleksja naukowa, jak i doświadczenie psychodeliczne. Styl charakterystyczny dla codzienności odznacza się następującymi cechami: specyficznym napięciem świadomości - pełną uwagą; epoché - powstrzymaniem się od wątpienia co do realności świata; czynnym działaniem, to jest spontanicznym kierowaniem się modelem projektu, czyli wypełnianiem planowanych działań; uspołecznieniem - podzielaniem intersubiektywnego świata na podstawie interakcji; 
szczególnym postrzeganiem czasu jako połączenia czasu wewnętrznego i kosmicznego (Schütz 2008: 34-35). Wymienione cechy, charakteryzujące strukturę życia codziennego, stanowią swoistą bazę ontologiczną, która pozwala nam w ogóle egzystować w świecie społecznym (Lejzerowicz-Zajączkowska 2003: 126).

Ważne jest, aby podkreślić, iż wszystkie z mikroświatów stanowią spójną całość, różniąc się jednak pewną podstawową cechą. Związane to jest bezpośrednio z kwestią napięcia świadomości, która jest główną cechą wyróżniającą dla stylu poznawczego każdego z mikroświatów tworzących Lebenswelt. Schütz w swych badaniach udowadniał, iż świat życia codziennego stanowi pewną matrycę podstawową, do której odniesione zostają doświadczenia pochodzące z innych światów. Tym samym w ramach świata życia codziennego porządkujemy nasze przeżycia pochodzące z innych mikroświatów. Na przykład sny tłumaczymy z perspektywy bycia na jawie i wówczas przypisujemy im jakieś sensy. Ma to sens o tyle, iż faktycznie czy to ze świata fantazji czy z morfeuszowych objęć, o ile nie doznamy uszczerbku na zdrowiu, zawsze wracamy do codzienności. Związany z tym jest także fakt, że największe napięcie świadomości charakterystyczne jest dla świata życia codziennego, najmniejsze natomiast dla mikroświata snu. W ramach tego kontinuum pomiędzy skrajnymi końcami wyznaczanymi przez sen i świat życia codziennego lokują się pozostałe mikroświaty z odpowiadającymi im stopniami napięcia świadomości.

Wykorzystując założenia teorii Schütza względem kryterium napięcia świadomości, zaproponowano, aby doświadczenie psychodeliczne rozumieć jako odmienny stan świadomości, i tym samym rozpatrywać w kategoriach jego koncepcji mikroświatów i stylów poznawczych, co pozwala na przeprowadzenie procedury Verstehen wobec fenomenu tegoż doświadczenia. $\mathrm{Na}$ zasadzie prostych analogii względem opisów poszczególnych mikroświatów, których dokonał austriacki filozof i socjolog, oraz dzięki wykorzystaniu danych pozyskanych z badań nad przypisywanymi odmiennym stanom świadomości sensom, podjęto próbę wskazania typowych cech doświadczenia psychodelicznego. Zdaniem Schütza bowiem pewne doświadczenia można traktować ogólnie jako ograniczone dziedziny znaczenia „,[...] jeśli wszystkie one odznaczają się swoistym stylem poznawczym oraz są - uwzględniając ów styl - nie tylko spójne, lecz również wzajemnie ze sobą zgodne" (Schütz 2008: 35). W prowadzonej analizie zbiór ten stanowiły opowieści, a dokładniej doświadczenia w nich zawarte, które doznawane były pod wpływem LSD, grzybów psylocybinowych i związku 4 HO-MET. Odwołując się do charakterystyk poszczególnych mikroświatów dokonanych przez Schutza (ograniczonych dziedzin znaczenia), wybrano z nich najważniejsze cechy, które posłużyły za definicyjne kryteria opisu doświadczenia psychodelicznego jako ograniczonej dziedziny znaczenia. $\mathrm{Na}$ ramę teoretyczno-analityczną złożyły się następujące wątki tematyczne:

1) poziom napięcia świadomości,

2) specyficzne epoché,

3) dominująca forma spontaniczności,

4) sposób doświadczania własnego ,ja”,

5) forma uspołecznienia (jak wygląda świat komunikacji i działania społecznego),

6) specyficzna perspektywa czasowa/postrzeganie czasu (Schütz 2008: 35). 


\section{DOŚWIADCZENIE PSYCHODELICZNE JAKO MIKROŚWIAT ORAZ PSYCHODELICZNY STYL POZNAWCZY}

Na wstępie konieczne jest, w celu przybliżenia poruszanej tu problematyki, przedstawienie w miarę możliwości pojemnej i funkcjonalnej definicji doświadczenia psychodelicznego dla co najmniej dwóch celów: sensownego pogodzenia ze sobą zjawisk i fenomenów wywoływanych na skutek stosowania środków o różnym potencjale i sile, jednak podobnej specyfice, oraz możliwości zestawienia ich z opisywanymi przez Schütza doświadczeniami refleksji naukowej, snu, zabawy czy fantazji. Tym samym „doświadczenie psychodeliczne rozumiane tu będzie jako występujący w opozycji do codziennego napięcia świadomości, odmienny stan umysłu w czasie czuwania, mogący charakteryzować się: zaburzeniami percepcji zmysłowej, wzmożoną wizyjnością, poczuciem odrealnienia, depersonalizacji, transcendencji ciała lub umysłu, osiagany na drodze zażywania odpowiednich substancji chemicznych, roślin bądź grzybów". W ten sposób doświadczenie psychodeliczne można odróżnić od innych unikatowych stanów bycia, takich choćby jak ekstaza, doświadczenie mistyczne, religijne, oświecenie czy śmierć ego, z którymi łączy je jednak jego niewysławialny, niedyskursywny charakter ${ }^{12}$ i konieczność rozpatrywania jego fenomenu w wyłącznie empirycznym, to jest opartym na bezpośrednim doświadczeniu, ujęciu ${ }^{13}$.

Jak pokazuje powyższa definicja, stan psychodeliczny względem pierwszej z interesujących nas kategorii (1) napięcia świadomości jest stanem jakościowo różnym od tego, $\mathrm{z}$ jakim mamy do czynienia $\mathrm{w}$ świecie życia codziennego. Pytanie brzmi, co jest dla tego stanu wyróżniające? Dziedzinom takim jak sen, fantazja czy imaginacja Schütz przypisywał wartościującą cechę redukowania świadomości (obniżania poziomu jej napięcia). W większości retrospektywne opisy przeżyć doznawanych na skutek stosowania określonych psychodelików pokazująjednak, że tak jednostronne i jednowymiarowe opisanie napięcia świadomości w stanie psychodelicznym byłoby błędne. Z jednej strony osoba znajdująca się w odmiennym stanie świadomości po spożyciu określonego psychodeliku może zanurzyć się w świecie silnych doświadczeń wizualnych i niemalże namacalnych wyobrażeń, które wskazywałyby na możliwość porównywania tego doświadczenia ze zbiorem dziedziny fantazji.

Eksplozja barw każdego odcienia. Króluje czerwień. Widzę zbliżające się do mnie paskudne sylwetki. Ale nie boję się. Gdzieś daleko widzę postać na tle zachodzącego słońca. Stoi i czeka. Na mnie? Na pewno nie. Na mnie nikt nie czeka. Czuję coś dziwnego. Otwieram oczy i wracam do rzeczywistości. [Bill]

Nie jest to jednak konieczne i nie wyjaśnia w pełni tego, co dzieje się ze świadomością w stanie psychodelicznym, gdyż równie dobrze znajdująca się w nim osoba może odbyć podróż nie tylko w świat fantazji, ale o wiele dalej, poza obszar własnego ,ja”, co można by

12 Na taką cechę specyficznego doświadczenia, jakim jest medytacja, wskazuje choćby Anna Sobolewska. 2009. Mapy duchowe wspótczesności: co nam zostało z Nowej Ery?, Warszawa: W.A.B., s. 338.

13 Definicja została bezpośrednio zaczerpnięta z pracy magisterskiej napisanej przez autora i zbudowana na bazie wykorzystanych do niej lektur oraz przemyśleń wynikających z badań własnych. 
określić mianem osobistej transcendencji. W tym przypadku napięcie świadomości redukowane jest jeszcze bardziej niż w przypadku fantazjowania i mocniej nawet niż w przypadku snu.

W tym momencie nastąpiło zerwanie ze mną kontaktu, sam zaś zostałem poniesiony przez wizję, która z mojego dotychczasowego doświadczenia bardziej przypominała głęboki stan szałwiowy niż ten po grzybach. Jest niemożliwością, żebym stwierdził kiedy miałem otwarte a kiedy zamknięte oczy. [Nautic]

Nie można jednak również jednoznacznie zawyrokować, że charakterystyczne dla stanu psychodelicznego jest zjawisko pogłębiania spadku napięcia świadomości, które byłoby w pewien sposób stopniowalne, od lekkiej redukcji, gdzie odpowiednikiem tego stanu byłaby fantazja, po silną redukcję, która przekraczałaby nawet stan snu. Raportujące o swych psychodelicznych doznaniach osoby podkreślają, że kierunek zmian, które zachodzą w obrębie ich świadomości, może mieć zupełnie przeciwstawny charakter, co wyraża się tym, iż uwaga skoncentrowana może zostać w pełni na życiu, świecie zewnętrznym i własnym ,ja”.

Myśląc, miałem wyłączoną sferę emocjonalną, a na wszystko spoglądałem wyłącznie rozumem, logiką. Efektem godzinnym przemyśleń było pogodzenie się i zaakceptowanie kilku rzeczy, z którymi nie mogłem sobie poradzić na co dzień [...]. [qarhodron]

Znane nam wszystkim wyostrzenie zmysłów wystąpiło tym razem z onieśmielającą wręcz mocą. Trawa była wyjątkowo gęsta i bogata w odmiany. Na chwilę mnie zatkało - jeszcze nigdy nie widziałem świata z tak oszałamiającą intensywnością, mimo że już sporo substancji przeszło przez mój organizm [...]. [HunT]

W tym sensie więc nie można mówić o doświadczeniu psychodelicznym ani w kategorii dziedziny fantazji ani też snu, gdyż może ono łączyć w sobie skrajne stany napięcia świadomości, które dla Schütza stanowiły podstawę dla wyróżnienia tych dwóch odrębnych mikroświatów. Doświadczenie psychodeliczne może prowadzić bowiem zarówno do doznań z zakresu utraty poczucia własnego ,ja”, jak i powodować uczucie zwiększenia świadomościowego napięcia, silniejszego poczucia siebie i uzyskania możliwości zdania sobie sprawy ze swej sytuacji, czego zdaniem Schütza nie możemy zrobić w czasie snu ${ }^{14}$. Dodatkowo podkreślić należy, że owo poczucie „samego siebie” może pod wpływem LSD, grzybów psylocybinowych czy 4 HO-MET'a wzrosnąć na tyle, że postrzegane będzie ono jako bardziej nasycone i pełniejsze, niż ma to miejsce w świecie życia codziennego. Wszystko zależne jest od kwestii otoczenia, psychicznego nastawienia osoby tripującej i dawki substancji. Te czynniki mają bezpośredni wpływ na to, jak silne będą wahania pomiędzy największym napięciem świadomości, wyrażającym się w pełnym zainteresowaniu wobec życia, a kompletnym jego brakiem, charakteryzującym się oceanicznym stanem rozpłynięcia.

14 Ten element teorii Schütza należy podać przynajmniej w wątpliwość, gdyż zjawisko świadomego śnienia, czyli tzw. Lucid Dream, jest czymś, choć niełatwym, to jednak możliwym do osiągnięcia. W takim śnie osoba śniąca jest w stanie zdać sobie sprawę, że śni. Pomijając nawet fakt, że w sieci odnaleźć można całe mnóstwo stron poświęconych tematyce i praktycznym technikom trenowania „świadomego śnienia”, niech każdy sam sięgnie pamięcią i zastanowi się, czy nigdy nie zdarzyło mu się zorientować, że śni? 
Kolejna z kategorii, która pozwala nam odróżnić stan psychodeliczny od innych dziedzin znaczenia to swoiste (2) epoché. Odnosząc się bezpośrednio do świata życia codziennego, Schütz stwierdził, że działania człowieka charakteryzują się epoché nastawienia naturalnego. Miałoby to oznaczać, że człowiek podczas codziennych rutynowych działań, odwrotnie niż fenomenolog, przekonany jest o realności i faktycznym istnieniu rzeczywistości, z którą się zderza i którą percypuje (Schütz 2008: 34). Jeszcze inne epoché charakterystyczne jest dla świata nauki. Podczas teoretycznej refleksji istota ludzka zawiesza pewność co do własnej egzystencji, odrzucając subiektywną perspektywę oglądu, chcąc w ten sposób znaleźć rozwiązania, które miałyby ponadjednostkowy wymiar z uwzględnieniem oczywiście odpowiednich zmiennych (czas, miejsce) (Schütz 2008: 48). Podczas doświadczenia psychodelicznego mamy do czynienia z jeszcze innym typem epoché, które ma skrajnie fenomenologiczną postać i przypomina w pewnym sensie Husserlowskie rozumienie tego terminu. Dla Husserla bowiem epoché „byłaby zabiegiem powstrzymywania się od naturalnego przeświadczenia o istnieniu danego nam z góry świata, redukcja zaś transcendentalnym rozjaśnieniem sensu tego przeświadczenia i, korelatywnie, sensu istnienia świata" (Czarkowski 1994: 36). Skorzystajmy $\mathrm{z}$ tego fragmentu jako użytecznej metafory. W odniesieniu bowiem do stosunku względem świata i jego prawdziwości, raportujące z psychodelicznej perspektywy osoby, w trakcie silnych doznań, mają poczucie jakoby dotychczasowa pewność co do realności świata codziennego została silnie podważona, a ich zmysłom ukazała się czysta, pełna, skrywana dotąd, „istota” świata, która wcześniej była dla nich niedostępna. Nawiązując do Huxleyowskiego efektu otwarcia drzwi percepcji, można by w tym miejscu powiedzieć, że w stanie psychodelicznym jednostki mają poczucie ujrzenia rzeczywistości taką, jaka faktycznie ona jest, i pozyskania skrywanej, blokowanej przez nasz mózg prawdy.

Czułem się, jak gdybym nagle zaczął oglądać świat takim, jaki jest naprawdę. [vIncent]

Jesteśmy w stanie nad-trzeźwości, nasza percepcja piękna nie uległa wykrzywieniu, czy zaburzeniu, lecz pewnemu wyostrzeniu - chłam przekształca się w gówno, myśl geniusza staje się bożą iskrą, ale... to, co widzę za zamkniętymi oczyma jest kwintesencją matematycznego, geometrycznego, topologicznego, symetrycznego piękna. [t.rydzyk]

Epoché stanu psychodelicznego jest swoiste i nie przystaje w pełni do żadnego z innych jego typów scharakteryzowanych przez Schütza. Odróżnia się ono bowiem tym, iż po fakcie „zdemaskowania” rzeczywistości i wzięcia jej w nawias, jednostka skierować się może zarówno w stronę dalszego podważania kolejnych jej płaszczyzn, dalszego zawieszania pewności, jak i uznać, że uzyskała ona dostęp do prawdziwej rzeczywistości i dalej korzystać z tego przywileju, ciesząc się „oświeceniem”, lub przeklinać ten moment jako przerażający i niebezpieczny.

To wszystko wprowadziło nieodwracalne zmiany, już nigdy nie będę mógł wrócić do rodziny i bliskich. Co ja teraz ze sobą zrobię? [...] Boże, jak ja bardzo chciałem znowu prowadzić to moje zwyczajne, nudne życie. Niczego bardziej nie pragnąłem na świecie. Błogosławiona niewiedza. [Szyderca] 
Kawałki mojego ja upadły i rozsypały się po panelach. Całe moje życie minęło przed moimi oczami. Kalejdoskop barw omamił mnie o pokazał, kim jestem. W tej jednej, krótkiej chwili zostałem ściągnięty kilka kolejnych poziomów w dół. [...] Zrozumiałem, jak wspaniałe mam życie. Jak cudowne. Przecież ja nie muszę się niczym przejmować, nic naprawiać. Jest tak, jak być powinno. $\mathrm{Z}$ całą pewnością. [vIncent]

Spektrum stanów, od wątpienia względem realności świata do całkowitego przekonania o dotarciu do jego istoty, może objawiać się podróżującemu naprzemiennie podczas trwania doświadczenia. To jak będzie natomiast wyglądał stosunek jednostki do otaczającej ją rzeczywistości oraz względem ukazujących się jej wizji, nie zawsze jest zależny od niej samej i w pewnym sensie może jej się arbitralnie przydarzać.

Następny aspekt, który należy poddać analizie, to (3) dominująca forma spontaniczności. Według Schütza, w życiu codziennym mamy do czynienia ze spontanicznością opartą na idei projektu. Chodzi tu o planowanie pewnych działań, które później - dzięki intencjonalnym aktywnościom - staramy się realizować, co prowadzi do tego, że mamy kontrolę nad swoim życiem. W opozycji do tego, ,ja” znajdujące się w stanie snu nie działa i nie ma możliwości sprawstwa (Schütz 2008: 43). W toku refleksji naukowej natomiast działanie nakierowane jest na rozumienie świata i opiera się tym samym również na idei projektu, który jednak jest zawieszony i czeka dopiero na możliwość realizacji w życiu codziennym (Schütz 2008: 43). W przypadku doświadczenia psychodelicznego idea projektu jako formy działania wydaje się nieprecyzyjna i zbyt wąska. Można powiedzieć, że działanie podejmowane choćby w świecie życia codziennego jest na coś nastawione, po coś wykonywane oraz - co nie mniej ważne z jakiegoś powodu ${ }^{15}$. Schütz wskazywał, iż dopiero „,[...] wówczas, gdy aktor zwróci się w stronę przeszłości i stanie się obserwatorem swoich własnych czynów, może z powodzeniem uchwycić przyświecający jego działaniom autentyczny motyw »ponieważ«" (Schütz 2008: 134). Treść trip raportów jasno pokazuje jednak, że samo doświadczenie oraz podejmowane w jego trakcie działania i wypowiadane kwestie, są najlepiej pojmowalne jeszcze w trakcie jego trwania. Próba thumaczenia sensu podejmowanych aktywności po doświadczeniu, które zazwyczaj w swym przebiegu są dobrze zapamiętane, okazuje się problemowa i, jak podkreślają to tripujące osoby, wyraźnie traci na jakości. Ujawnia się tutaj specyficzny charakter doświadczenia psychodelicznego jako niewysławialnego i niedyskursywnego. Znajdujący się w stanie psychodelicznym doświadczają nie tylko efektów swoich działań, ale mogą także jednocześnie zidentyfikować związane z nimi subiektywne motywacje. To, co robimy, dlaczego i po co w stanie psychodelicznym, ma swój niepowtarzalny sens właściwie tylko podczas doświadczenia, umykając uchwyceniu w ramy z perspektywy świata życia codziennego czy refleksji naukowej. Nawet jeżeli podczas doświadczenia psychodelicznego narzuca się nam jakaś idea projektu, to jednak jest ona ulotna, podobnie jak trwanie psychodelicznej substancji w naszym organizmie.

Kwas najpierw doprowadził mnie do rozpaczy, gdyż bez niego nie byłbym w stanie sam wymyślić tego świata na papierze. Teraz zostawia mnie bez języka, który potulnie zwinął się w rulonik i zapadł w gardło. Potem słowo odżywa, a ja widzę jego ciężar, to, co mówi, a przede wszystkim to, czego nie mówi. A to, czego nie widzimy, jest znacznie ważniejsze od tego, co widzimy, a to

15 Odnosi to się wprost do opisywanych przez Schütza motywów typu „ażeby” i „ponieważ”, na których dokładne opisywanie brak tutaj miejsca. 
czego nie napiszę, będzie znacznie ważniejsze od tego, co napiszę [...] Przestaję zapisywać moje notatniki. Wszystko, co napisałem, wydaje mi się teraz pozbawione sensu. Strawił mnie ogień, ten który płonie tylko po to, by oczyścić duszę i pozostawić nas pokornych i cichych. [Pilgrim]

Następne z kryteriów, na które powoływał się Schütz, to (4) doświadczanie własnego „ja”. W mikroświecie życia codziennego ,ja” jest w pełni świadome, zintegrowane i ma poczucie sprawstwa. Skupienie na ,ja” może mieć wówczas różny poziom intensywności, od silnego, gdy prowadzimy wewnętrzny pierwszoosobowy dialog, po stosunkowo słabszy, gdy pochłonięci jesteśmy rozmową z kimś. Gdy podejmujemy refleksję naukową, ,ja” jest celowo redukowane, aby zminimalizować wpływ pierwiastka subiektywnego. W świecie snu natomiast większości osób uzmysłowienie sobie bycia jako ,ja” w ogóle się nie zdarza - sen nie jest świadomy. Fenomen doświadczania własnego ,ja” w stanie psychodelicznym jest czymś niezwykle heterogenicznym i zmiennym. Jak już wspomniano przy omawianiu innych kategorii, doświadczanie własnego ,ja” w odmiennym stanie świadomości wywołanym na skutek działania psychodeliku, może bowiem urosnąć do problemu pierwszoplanowego, jak i stać się czymś nieistotnym, bądź czasowo w ogóle niedostępnym. Związane to jest z kwestią kierowania uwagi, która w stanie psychodelicznym ulega spotęgowaniu do tego stopnia, iż wszystko, co znajduje się poza obiektem bezpośredniego zainteresowania, zdaje się w ogóle nie istnieć. Poszerzenie pola percepcji jest zatem w pewien sposób także jego zawężeniem, gdyż dokładniejsze skupienie się na danym obiekcie, choćby na sobie, prowadzi do silnego odcięcia kontaktu z innymi obiektami. Zatem wzrost odczuwania, percypowania siebie samego w stanie psychodelicznego upojenia, ma charakter, który zdaje się przekraczać zarówno codzienne doświadczanie własnego ciała, jak i naszej sfery mentalnej. W stanie psychodelicznym odczuwanie ,ja” jest zmienne i zdaje się wyrażać w sposób procesowy. Najczęściej ów proces (często jest to początek doświadczenia) wyraża się w silnym szoku poznawczym, który w kontekście poczucia własnego ,ja” odznacza się rosnącym odrealnieniem względem własnego ciała (objawy somatyczne), własnych myśli oraz otaczającego świata.

Wyciągana ręka do kranu z wodą zapadła mi głęboko w pamięci. Wyglądała jak nie moja, nie czułem jej fizycznie, tylko widziałem oczami nienaturalnie długą rękę, która sięgała daleko do pokrętła z zimną wodą. Odczuwanie dystansu było bardzo zaburzone. [ayahuasca]

Tego typu efekty są najczęstsze i choć widać, że wprowadzają one poznawczy chaos, to jednak pozwalają na zachowanie kontaktu z rzeczywistością oraz samym sobą. Doświadczenie psychodeliczne może jednak oddziaływać na ,ja” jednostki o wiele silniej, prowadząc ją w stronę kompletnego rozpadu, rozpłynięcia. Tripujące osoby często zwracają uwagę, że podczas doświadczenia czuły defragmentację własnego ,ja”. Od początkowego zaburzenia postrzegania siebie, braku pewności co do własnego ,ja”, swoistej depersonalizacji i oceanicznego rozpłynięcia, tripujący mogą doznać również uczucia połączenia i integracji ze światem zewnętrznym, najczęściej utożsamianym z naturą, bądź silnego związku z gatunkiem ludzkim i obcymi kulturami, przy jednoczesnym zachowaniu świadomości siebie, swoich myśli i ciała ${ }^{16}$.

16 O tego typu doświadczeniach pisał między innymi S. Grof, czeski lekarz medycyny, znany ze swoich metod leczenia zaburzeń psychicznych spowodowanych stosowaniem LSD. Zob.: Stanislav Grof. 2012. Obszary nieświadomości: Raport z badań nad LSD, Warszawa: Wydawnictwo A. 
[...] poczucie oceanicznego zespolenia z tym co nazywam kosmosem/kosmiczną jednością, a inni nazwą Bogiem/Naturą [...]. Doświadczenia pozaosobowe, doświadczenia ponownego połączenia się z kosmosem, doświadczania siebie jako odrębnego, całego świata/galaktyki, bycie czystymi emocjami, utożsamianie się z całą ludzkością, z dziwnymi kulturami (szamański charakter), duchowymi stanami, odczuwanie ich i z perspektywy własnego „JA”, jak i chwilę potem bycie nimi (przy zaniku ego). Wszystko to miało silny duchowy pierwiastek. Uczucie zupełnie nie dające się ujać słowami. [herbata]

W przypadku stanu psychodelicznego mówić zatem można zarówno o lekkich zaburzeniach w postrzeganiu ,ja” (niepewność co do tego, kto wypowiada słowa płynące z naszych ust, czy są one w ogóle nasze), o silnych stanach rozpłynięcia ,ja” i kompletnej depersonalizacji, jak i odczuwaniu ,ja” jako części szerszego systemu, pewnej ponadjednostkowej całości w postaci natury, całego ludzkiego gatunku, bądź wszystkich żywych organizmów, przy jednoczesnym zachowaniu poczucia własnej odrębności i świadomości. Z tak szerokim wachlarzem niezwykle intensywnych i specyficznych doznań, w odniesieniu do postrzegania własnego ,ja", nie zderzamy się w żadnym z innych mikroświatów opisywanych przez Schütza.

Nie mniej poznawczo ciekawe są (5) formy uspołecznienia, typowe dla stanu psychodelicznego. Pomimo poważnych zmian w odczuwaniu własnego ,ja" wiążących się niejednokrotnie z kompletną utratą kontaktu ze światem i samym sobą ludzie pod wpływem LSD, grzybów psylocybinowych czy 4 HO-MET'a są w stanie wchodzić w interakcje z innymi i podejmować działania grupowe. Żeby nie banalizować tematu, wskazane tu zostaną najbardziej specyficzne cechy dotyczące procesu komunikacji, których nie odnajdziemy w innych dziedzinach znaczenia. Typowym zjawiskiem dla stanu psychodelicznego jest trudność w wyrażaniu myśli, opisywaniu własnych stanów i prowadzeniu komunikacji. Co jednak szczególnie ciekawe, pomiędzy wspólnie tripującymi osobami, potrafi nawiązać się silna więź i pozawerbalne porozumienie, które określić by można jako fenomen św i a d o m oś c i zbi o row ej j7. Opiera się on na silnym przeświadczeniu, wierze co do tego, że silnie subiektywne i w wielu aspektach niepodlegające możliwości opisu elementy doświadczenia są odczuwane przez towarzyszy „podróży” w bardzo zbliżony, jeśli nie identyczny sposób, co nie wymaga potwierdzenia na drodze szczegółowej wymiany zdań czy dyskusji.

Wszystko przebiegało w ogromnej symbiozie z przeżyciami innych. Często wymyślaliśmy coś razem i brnęliśmy, ślepo wierząc, że nasze fazy są jednym wspólnym przeżyciem. [unknown]

Pewnie działo się to też dlatego, ponieważ wiele nie dopowiadaliśmy w naszych rozmowach. Często słowa były zbędne, gdyż nasza trójka rozumiała się bez tego doskonale [...] Kilka dni po tripie rozmawiałem z przyjacielem i spytałem się go o naszą dyskusję w trójkącie. Okazało się, że on też odebrał podobnie tę sytuację - czuł, jakbyśmy stawali się wspólną świadomością. [Konkormir]

Werbalna komunikacja może również zostać czasowo całkowicie pominięta jako niefunkcjonalna. Dla tripujących osób często wystarczające są wymiany spojrzeń, min, gestów

17 W kontekście tego opracowania nie jest szczególnie istotne to, czy świadomość zbiorowa jest czymś obiektywnie zachodzącym i możliwym do potwierdzenia. Tutaj liczy się jedynie czysty fenomen tego zjawiska, który dobrze odwzorowuje subiektywne odczucia podmiotów go doświadczających. 
Fenomenologiczna jedność doświadczenia psychodelicznego - analiza treści trip raportów

bądź hasłowe komentarze, które wywołują atmosferę porozumienia i docierania do wspólnych sensów, które wydają się wręcz fizycznie odczuwalne.

Porozumiewaliśmy się sukcesywnie mniej za pomocą słów, a bardziej za pomocą kształtów i symboli, aż wreszcie, ktoś, kto coś przekazywał, „otwierał” doświadczenie, które przeżywali wszyscy na raz. [Own3d]

Częste problemy z wyrażaniem stanów emocjonalnych, jak i opisywaniem percypowanych zmian wizualnych zachodzących w otoczeniu (OEV - open eye vizualizations), prowadzić mogą do tego, iż język odbierany jako coś ograniczającego, zbyt schematycznego i niewystarczalnego podlega procesowi transformacji i swoistej rozbudowie na potrzeby opisu i wyrażenia stanów niewysławialnych w ramach języka standardowego. Mówić tu można wprost o swoistym słowotwórstwie, o którego fenomenie w odniesieniu do doświadczeń z pejotlem wspominał między innymi Witkacy (Witkiewicz 2004: 92).

Ostatnią z kategorii, którą zgodnie z założeniami teorii Schütza należy tutaj poddać analizie jest (6) perspektywa czasowa. Patrząc na początku na mikroświaty, które charakteryzował austriacki socjolog, to w świecie snu, jego zdaniem czasu najzwyczajniej nie ma. Nie należy on do zjawisk, które wchodziłyby w obręb percepcji osoby śniącej w ogóle. Jeżeli w śnie nabywamy świadomości tego, że z czasem jest „,coś nie tak”, to znaczy, że de facto go nie ma, to według niektórych śnić zaczynamy w jakościowo inny sposób, w sposób świadomy ${ }^{18}$. Schütz w kwestii tej dziedziny znaczenia dodaje, że teraźniejszość, przeszłość i przyszłość splatają się we śnie w jedno, nie mając swego miejsca „w porządku czasu obiektywnego” (Schütz 2008: 44). W odniesieniu do świata fantazji, stwierdza natomiast, iż ,[...] wyobrażającej »ja« może poprzez swoje fantazje wyeliminować wszystkie cechy czasu standardowego, z wyjątkiem jego nieodwracalności” (Schütz 2008: 41). Wiąże się to z tym, iż fantazje podlegają projektowaniu przez umysł, który funkcjonuje w ramach dureé, czyli czasu wewnętrznego, który jest swoisty dla każdego z nas z osobna, i nie przestaje funkcjonować nawet wówczas, gdy marzymy. W przypadku stanu psychodelicznego czas jest czymś abstrakcyjnym, niestabilnym i niemieszczącym się w dobrze znanych nam ramach.

(około 17.10) Około tego momentu pojęcie upływu czasu było już kompletną abstrakcją. [Ziggie]

[...] tracę poczucie czasu i wydaje mi się, że płynie on błyskawicznie - godzina minęła mi w mgnieniu oka, a kolejne trzy minuty zdają się rozciagać w nieskończoność. [Everett]

Scharakteryzowanie czasu jako trudnego do określenia i zmierzenia w stanie psychodelicznym byłoby jednak niepełne. Konieczne jest również zwrócenie uwagi na relację łączącą ze sobą kategorie przeszłości, teraźniejszości i przyszłości. Silne podobieństwo występuje tutaj w odniesieniu do dziedziny snu, gdyż trzy wymiary czasu wydają się w stanie

18 Jedną z cech mających występować powszechnie u świadomie śniących osób, oprócz problemów z czytaniem wyśnionego tekstu czy powolnymi, ociężałymi ruchami podczas ucieczki przed zagrożeniem, ma być chaotyczne działanie zegarów, które wskazują co chwilę inną godzinę. Odniesienie do czasu poprzez spojrzenie na zegar, jest również jednym ze sposobów przejścia ze stanu zwykłego snu, do świadomego. Wątki dotyczącego wspominanego już wcześniej Lucid Dream poruszane są również na forum talk.hyperreal.info. 
psychodelicznym ulegać rozmyciu i wzajemnemu scaleniu, jednak, co wyróżniające w tym przypadku, typowa okazuje się dominacja czasu teraźniejszego. Metafory trafnie oddającej ten fenomen dostarcza Frederic Jameson, przyrównujący ponowoczesną jednostkę do schizofrenika, który mając problemy z poczuciem ciągłości czasu, doświadcza zintensyfikowanego odczuwania teraźniejszości. ,[...] świat staje przed schizofrenikiem ze wzmożoną intensywnością, niesie uczucia tajemnicze, przytłaczające swym ciężarem i promienieje mamiącym blaskiem. To jednak, co mogłoby się nam wydawać doświadczeniem pożądanym poszerzeniem pola percepcji, zmysłowa lub też halucynogenna intensyfikacja zazwyczaj monotonnej i swojskiej okolicy - tutaj odczuwana jest jako utrata, jako nierzeczywistość" (Jameson 1997: 205). Intuicyjny charakter tego opisu i podkreślenie w nim zjawiska silnego konfrontowania się z „tu i teraz”, wydają się dobrze pasować do fenomenu doświadczania czasu w stanie psychodelicznym. Postrzegany w naszej kulturze w sposób linearny czas ulega bowiem rozpłynięciu, stając się czymś abstrakcyjnym i sprawiając, że rozpadowi podlega typowa dla świata życia codziennego relacja, w której to czas wewnętrzny podmiotu (dureé) przecina się z czasem kosmicznym. W stanie psychodelicznym świadomość może zostać wyciagnięta z naturalnej, „uniwersalnej struktury temporalnej intersubiektywnego świata”, jak powiedziałby Schütz, co owocuje wówczas zintensyfikowaną ekspozycją i uwypukleniem czasu wewnętrznego, dającą efekt wzmożonego doświadczania teraźniejszości. Mówiąc inaczej, w stanie psychodelicznym, tripująca osoba, gdy skieruje uwagę na tu i teraz (wyswobadzając się z natłoku fraktalowych wizji bądź niemalże namacalnych marzeń), zderza się z problemem by cia w c zasie bardziej dotkliwie, niż ma to miejsce w przypadku każdej z pozostałych dziedzin znaczenia.

Czas jest domeną naszych fizycznie ograniczonych umysłów. Świadoma myśl i materia całego wszechświata tańczą ze sobą na hiperpłaszczyźnie. Ego nie istnieje, umarło - osobowość zostaje ukazana w całokształcie, jak na talerzu, po czym poskromiona niczym węzeł gordyjski. W psychice zachodzi mistyczna, cudowna metamorfoza. Perfekcyjnie czysty umysł emanujący harmonia. Kwintesencja człowieczeństwa. [...] Nie szperam w zakamarkach pamięci, aby przypomnieć sobie coś, o czym chciałbym teraz myśleć, gdyż każda myśl jest TU i TERAZ. Zostaje automatycznie przeanalizowana, a każdy dręczący problem mentalny rozwikłany w sposób prosty i doskonały. [Zjemtwepachy]

\section{ZAKOŃCZENIE}

Wyniki przeprowadzonej analizy pokazują, iż doświadczenie psychodeliczne nie poddaje się w pełni założeniom teoretycznym zaproponowanym przez Schütza. W ramach kryterium napięcia świadomości, które pozwoliło austriackiemu socjologowi na zbudowanie kontinuum: świat życia - sen, brak jest możliwości wskazania miejsca, które na tej osi miałoby zajmować doświadczenie psychodeliczne, co wiąże się z tym, iż odzwierciedla ono cechy charakterystyczne dla różnych mikroświatów. Pojawia się zatem pytanie, czy sensowne i możliwe jest traktowanie fenomenu doświadczenia psychodelicznego w języku Schütza jako spójnej dziedziny znaczenia i dążenie do wskazania jego niepowtarzalnych i świadczących o jego odrębności cech? Pomimo że doświadczenie psychodeliczne jest zjawiskiem niezwykle 
heterogenicznym, zmiennym, a jego przebieg zależny jest od wielu czynników, z których nie wszystkie poddają się kontroli, to jednak wydaje się, iż zasadne jest traktowanie go jako spójnego doświadczenia i możliwe jest podejmowanie prób jego obiektywizacji. Choć w przypadku psychodelicznej podróży typowe jest nakładanie się na siebie cech i zjawisk, które odsyłają nas do poszczególnych mikroświatów opisanych przez Schütza (snu, fantazji, pogłębionej refleksji etc.), co wiąże się bezpośrednio z charakterystycznymi zmianami napięcia świadomości, które można identyfikować, stosując zaproponowaną przez Schütza kategorię szoku, to jednak ta sama kategoria pozwala na uchwycenie cech typowych dla tego konkretnego stanu. Doświadczenie psychodeliczne jest czymś całościowym i odrębnym od innych dziedzin znaczenia, gdyż ma jasno zarysowany początek i koniec (podobnie jak sen, marzenie, refleksja naukowa etc.). Początek doświadczenia identyfikować można choćby dzięki efektowi body load'u, czyli całokształtu odczuć zmysłowych, najczęściej nieprzyjemnych (choćby postępujące odrealnienie względem ciała), które pojawiają się na skutek „wchodzenia” substancji. Najwyższy punkt przeżycia określany mianem peak'u oraz tak zwane zejście, czyli stopniowy spadek działania określonej substancji, są również na tyle wyraźne, że umożliwiają dokładne wskazanie granic wyznaczających ramy doświadczenia psychodelicznego, co w języku Schütza określić należy jako odrębną, ograniczoną dziedzinę znaczenia. Wskazuje na to również specyfika każdej z poszczególnych kategorii poddanej analizie, która każdorazowo wykracza poza jej rozumienie przedstawione w myśli Schütza.

Próba ograniczenia przeżycia psychodelicznego, którego fenomenu doświadczyć można jedynie w sposób bezpośredni i subiektywny, w wąskich ramach jednej teorii czy filozofii, wydaje się zadaniem dość karkołomnym. Powyższa analiza uwypuklić miała ten problem, ale także pokazać, że podejmowanie prób radzenia sobie z materiałem przesiąkniętym silnym wartościowaniem i subiektywizmem może dać poznawczo ciekawe rezultaty. Wykorzystanie języka teorii Schütza, a zwłaszcza jego kryteriów napięcia świadomości, epoché, form spontaniczności/działania, doświadczania własnego ,ja”, uspołecznienia oraz postrzegania perspektywy czasowej dało niezbędne narzędzia pozwalające na oswojenie psychodelicznych opowieści, podjęcie dialogu z nimi oraz ich lepszego zrozumienia. Powyższe próby dążyły zatem zwłaszcza do tego, aby subiektywne psychodeliczne przeżycia, które zyskały intersubiektywny charakter dzięki przelaniu ich przez internautów na treści trip raportów, zostały potraktowane nie jako jednostkowe, odrębne i nieprzystające do siebie fenomeny, ale w ramach pewnych założeń - jako spójne doświadczenie. Jeśli cel działań harvardzkich psychologów określić w pewnym sensie jako edukacyjny, to w przypadku powyższej analizy i jej poziomu, można by mówić najpełniej o celu czysto poznawczym, ale także porządkującym, który w założeniu ma otwierać drogę do dalszych analiz.

\section{BIBLIOGRAFIA}

Czarkowski, Józef. 1994. Filozofia czystej świadomości: Redukcja, refleksja, czysta świadomość w fenomenologii transcendentalnej Edmunda Husserla, Toruń: UMK.

Gibbs, Graham. 2011. Analizowanie danych jakościowych, tłum. M. Brzozowska-Brywczyńska, Warszawa: PWN. 
Grof, Stanislav. 2012. Obszary nieświadomości: Raport z badań nad LSD, Warszawa: Wydawnictwo A.

Jameson, Frederic. 1997. Postmodernizm i społeczeństwo konsumpcyjne, w: Ryszard Nycz (red.), Postmodernizm: antologia przekładów, Kraków: Baran i Suszczyński Sp. z o.o., s. 190-213.

Leary, Timothy. 1998. Polityka ekstazy, Kraków: EJB.

Lejzerowicz-Zajączkowska, Barbara. 2003. Człowiek w świecie sensów: filozoficzne podstawy fenomenologicznej socjologii Alfreda Schütza, Płock: Novum.

Schütz, Alfred. 2008. O wielości światów. Szkice z socjologii fenomenologicznej, Kraków: Zakład Wydawniczy Nomos.

Sobolewska, Anna. 2009. Mapy duchowe współczesności: co nam zostało z Nowej Ery?, Warszawa: W.A.B.

Witkiewicz, Stanisław Ignacy. 2004. Narkotyki, niemyte dusze, Warszawa: PIW.

Włodarek, Jan i Marek Ziółkowski. 1990. Teoretyczny i empiryczny status metody biograficznej we współczesnej socjologii, w: Jan Włodarek i Marek Ziółkowski (red.), Metoda biograficzna $w$ socjologii, Warszawa: PWN, s. 3-9.

\section{PHENOMENOLOGICAL CONSISTENCY OF A PSYCHEDELIC EXPERIENCE - TRIP REPORTS ANALYSIS}

The subject of the present paper is to focus on the psychedelic experience, perceived by the author as a coherent, repeatable phenomenon. This was enabled by analyzing stories collected from people who admitted to using specific psychoactive substances. The author was inspired by a group of University of Harvard researchers who were actively involved in the American counter-culture of the 1960s. This group attempted to explain the following phenomenon using Eastern philosophy and religion. In contradiction to this idea, the author proposes a different method based on Western traditions of philosophy and social sciences.

Keywords: altered states of consciousness, psychedelic experience, phenomenological sociology, Alfred Schütz 